\title{
Effect of Thyroid Hormone on Slow Calcium Channel Function in Cultured Chick Ventricular Cells
}

\author{
Donghee Kim, Thomas W. Smith, and James D. Marsh \\ Cardiovascular Division and Department of Medicine, Brigham and Women's Hospital, \\ and Department of Medicine, Harvard Medical School, Boston, Massachusetts 02115
}

\begin{abstract}
The hyperthyroid state is associated with increased myocardial contractility. To clarify responsible mechanisms, we examined the effects of thyroid hormone on slow Ca channels, beta-adrenergic receptors, transsarcolemmal ${ }^{45} \mathrm{Ca}$ flux and cytosolic free calcium in cultured chick ventricular cells. Compared with cells grown without triiodothyronine $\left(\mathrm{T}_{3}\right)$, cells grown in $10 \mathrm{nM} \mathrm{\mathbf {T } _ { 3 }}$ possessed (a) 67\% $(P<0.05)$ more dihydropyridine ${ }^{3} \mathrm{H}$-PN200110 binding sites, $(b) 24 \%(P<0.05)$ more beta-adrenergic antagonist ${ }^{3}$ H-CGP12177 binding sites, $(c)$ a $57 \%(P<0.05)$ greater nifedipine-sensitive initial ${ }^{45} \mathrm{Ca}$ uptake rate, and $(d)$ a $31 \%(P$ $<0.05)$ greater nifedipine-sensitive ${ }^{45} \mathrm{Ca}$ uptake rate in response to BAY k 8644. Time-averaged mean intracellular free Ca concentration $\left([\mathrm{Ca}]_{\mathfrak{i}}\right)$ measured with fura-2, total protein content, and dissociation constant values for ${ }^{3} \mathrm{H}-\mathrm{PN} 200-110$ or ${ }^{3} \mathrm{H}$ CGP12177 binding was not significantly different in the two groups of cells. BAY $\mathbf{k} 8644(1 \mu \mathrm{M})$ increased mean [Ca], 2.85or 2.16-fold in cells grown with or without $10 \mathrm{nM} \mathrm{T}_{3}$, respectively. $l$-Isoproterenol $(1 \mu \mathrm{M})$ increased $[\mathrm{Ca}]_{1} 1.53$ - or 1.28 -fold in cells grown with or without $10 \mathrm{nM} \mathrm{T}_{3}$, respectively. We conclude that thyroid hormone augments transsarcolemmal $\mathrm{Ca}$ influx, at least in part via slow $\mathrm{Ca}$ channels associated with increased numbers of these channels. $T_{3}$-treated cells appear to be more responsive to the effects of BAY $k 8644$ or isoproterenol on $[\mathrm{Ca}]_{i}$.
\end{abstract}

\section{Introduction}

Hyperthyroidism is associated with increased heart rate, myocardial contractility, and cardiac output (1-3). Previous studies from our own and other laboratories suggest that thyroid hormone can act directly on heart cells, presumably via nuclear receptors, to produce an increase in contractile state as well as in protein synthesis (3-6). However, the cellular mechanisms by which thyroid hormone alters myocardial contractile state are not fully understood. Several studies have demonstrated the ability of thyroid hormone to increase myosin ATPase activity in the rat and rabbit by shifting the relative proportions of isoenzyme forms such that the form with higher ATPase activity (V1) predominates $(3,7,8)$. These findings have led to the hypothesis that enhancement of myocardial contractility by thyroid hormones is the result of increased cardiac myosin ATPase ac-

Address correspondence to Dr. Donghee Kim, Cardiovascular Division, Brigham and Women's Hospital, 75 Francis Street, Boston, MA 02115.

Received for publication 11 September 1986 and in revised form 23 March 1987

J. Clin. Invest.

(c) The American Society for Clinical Investigation, Inc.

$0021-9738 / 87 / 07 / 0088 / 07 \quad \$ 2.00$

Volume 80, July 1987, 88-94 tivity. However, thyroid hormone has also been reported to alter Ca uptake by sarcoplasmic reticulum (9-14), to stimulate plasma membrane Ca-ATPase activity $(4,15,16)$, and also to increase the numbers of sarcolemmal sodium pump sites (17-19). Therefore, the mechanisms by which myocardial contractility is enhanced in response to thyroid hormone appear to include altered $\mathrm{Ca}$ handling by sarcoplasmic reticulum and also changes in sarcolemmal membrane function that would directly influence the excitation-contraction coupling process.

We have previously reported that in monolayers of cultured chick embryo ventricular cells, thyroid hormone causes a timeand concentration-dependent increase in the rate of transsarcolemmal $\mathrm{Ca}$ movement and also in the size of the $\mathrm{Ca}$ pool associated with the sarcoplasmic reticulum (4). It is likely that the increased rate of inward $\mathrm{Ca}$ movement is partly responsible for enhanced myocardial contractility. To explore this issue further, in the present study we examined mechanisms that could potentially augment $\mathrm{Ca}$ entry. We tested the hypothesis that the increased rate of $\mathrm{Ca}$ influx produced by thyroid hormone is due to elevated numbers of slow $\mathrm{Ca}$ channels in the sarcolemmal membrane. In addition, we determined changes in ${ }^{45} \mathrm{Ca}$ uptake via nifedipine-sensitive pathways in response to growth in the presence of elevated levels of thyroid hormone as well as cytosolic free $\mathrm{Ca}$ concentrations in the presence or absence of the $\mathrm{Ca}$ channel agonist BAY k 8644 or the beta-adrenergic agonist isoproterenol.

\section{Methods}

Tissue culture. Monolayer cultures of spontaneously contracting chick embryo ventricular cells were prepared as described previously (20). Hearts of 10-d-old chick embryos were removed and individual ventricular cells were isolated by trypsinization. The final concentrations of $\mathrm{K}$, $\mathrm{Na}$, and $\mathrm{Ca}$ in culture media were $4.0,137$, and $0.97 \mathrm{mM}$ respectively. The cell suspension was placed in plastic culture dishes containing 25-

monolayers were subsequently used in ion flux and contractility studies. Cultures were incubated in a humidified $5 \% \mathrm{CO}_{2}, 95 \%$ air atmosphere at $37^{\circ} \mathrm{C}$. Confluent monolayers, in which at least $80 \%$ of the cells exhibited spontaneous synchronous contraction, developed by 2-3 d of incubation.

After the cells were allowed to grow in culture medium containing $6 \%$ fetal calf serum for $48 \mathrm{~h}$, the medium was replaced with serum-free medium containing $1 \mu \mathrm{M}$ insulin, $50 \mathrm{nM}$ transferrin, $1 \mathrm{nM}$ selenium, 1 $n M$ progesterone, and either no triiodothyronine $\left(\mathrm{T}_{3}\right)^{1}$ or $10 \mathrm{nM} \mathrm{T}_{3}(21)$. The final concentrations of $\mathrm{K}, \mathrm{Na}$, and $\mathrm{Ca}$ in the serum-free and serumcontaining media were held constant. Cells continued to contract spontaneously and remained fully viable for at least $2 \mathrm{wk}$ in the serum-free medium.

Receptor binding studies. The numbers of slow calcium channels and beta-adrenergic receptors in intact myocytes were estimated from

1. Abbreviations used in this paper: $[\mathrm{Ca}]_{\mathrm{i}}$, intracellular free $\mathrm{Ca}$ concentration; $\mathrm{T}_{3}$, triiodothyronine. 
specific binding of the calcium channel antagonist ${ }^{3} \mathrm{H}-\mathrm{PN} 200-110$ and the beta-adrenergic antagonist ${ }^{3} \mathrm{H}-\mathrm{CGP} 12177$, respectively. ${ }^{3} \mathrm{H}-\mathrm{PN} 200$ 110 (Amersham Corp., Arlington Heights, IL) is a lipophilic dihydropyridine $\mathrm{Ca}$ channel antagonist with high affinity and specificity for the Ca channel $(22,23) .{ }^{3} \mathrm{H}-\mathrm{CGP} 12177$ (Amersham Corp.) is a relatively hydrophilic beta-adrenergic antagonist that binds predominantly, if not exclusively, to cell surface beta-adrenergic receptors $(24,25)$. Cells were grown on six-well plates in the presence or absence of $10 \mathrm{nM} \mathrm{T}_{3}$ for 48 h. Cells were washed with Hepes-buffered medium (pH 7.35) and then incubated with concentrations of ${ }^{3} \mathrm{H}-\mathrm{PN} 200-110$ ranging from 100 to $1,400 \mathrm{pM}$, or ${ }^{3} \mathrm{H}$-CGP12177 ranging from 50 to $2,000 \mathrm{pM}$ for $30 \mathrm{~min}$ (steady state) at $37^{\circ} \mathrm{C}$. Preliminary experiments have shown that in the concentrations used, at $37^{\circ} \mathrm{C}$, association of PN200-110 with its binding site is complete by $15-20$ min; CGP12177 binds with a similar time course. Binding was terminalted by rapidly washing the cells in each well three times with $4 \mathrm{ml}$ of cold Hepes-buffered medium $\left(2-4^{\circ} \mathrm{C}\right)$. Cells were then solubilized with $1 \%$ sodium dodecyl sulfate (SDS) and $10 \mathrm{mM}$ sodium borate. Radioactivity was assayed using a liquid scintillation spectrometer (60\% efficiency; LKB Instruments Inc., Bromma, Sweden) and protein content was measured by the method of Lowry et al. (26). Nonspecific ${ }^{3} \mathrm{H}-\mathrm{PN} 200-110$ or ${ }^{3} \mathrm{H}-\mathrm{CGP} 12177$ binding observed in the presence of $10 \mathrm{nM}$ nonlabeled PN200-110 or $1 \mu \mathrm{M}$ l-propranolol, respectively, was subtracted from the total binding observed in its absence to calculate specific binding. Radioligand binding curves were analyzed with the iterative nonlinear least squares method of Munson and Rodbard (27) on a VAX 7800 computer to determine ligand affinity and number of binding sites.

$\mathrm{Ca}$ fluxes. For determination of $\mathrm{Ca}$ uptake by cultured chick ventricular cells, glass coverslips with attached monolayers were obtained from each culture. The coverslips were preincubated in Hepes-buffered medium ( $\mathrm{pH} 7.35$ ) containing $5 \mathrm{mM}$ Hepes ( $N$-2-hydroxyethylpiperazine, $N$-2-ethane sulphonic acid), $0.9 \mathrm{mM} \mathrm{CaCl}, 4 \mathrm{mM} \mathrm{KCl}$, and $0.5 \mathrm{mM}$ $\left.\mathrm{MgCl}_{2}\right)$ for $10 \mathrm{~min}$ and then incubated in medium containing ${ }^{45} \mathrm{Ca}(5$ $\mu \mathrm{Ci} / \mathrm{ml}$ ). For studies using BAY $\mathrm{k} 8644$, the ${ }^{45} \mathrm{Ca}$ uptake rate was determined by the following method. Cells were preincubated in Ca-free Hepesbuffered medium $\left(37^{\circ} \mathrm{C}\right)$ for $5 \mathrm{~min}$ and then incubated in $0.9 \mathrm{mM} \mathrm{Ca}$ medium containing ${ }^{45} \mathrm{Ca}$. BAY k 8644, when used, was present in both media. This extra step was necessary to ensure a known ${ }^{45} \mathrm{Ca}$ specific activity at the cell surface. Without this step, the apparent responses to BAY k 8644 or isoproterenol exposure were blunted, probably due to relatively slow mixing of ${ }^{45} \mathrm{Ca}$ with unlabeled $\mathrm{Ca}$ bound to sites at the cell surface. All incubations were at $37^{\circ} \mathrm{C}$ under conditions identical to those for the ligand binding studies. After the desired uptake period, coverslips were removed from the uptake medium and washed for $5 \mathrm{~s}$ each in three $80-\mathrm{ml}$ vol of Hepes-buffered medium $\left(4^{\circ} \mathrm{C}\right)$. This washing procedure has been shown to remove $>99 \%$ of ${ }^{51} \mathrm{Cr}$ after incubating the cells with the interstitial space marker ${ }^{51} \mathrm{Cr}$-EDTA, and also to remove ${ }^{45} \mathrm{Ca}$ bound to the cell surface sites (20). Cells were then scraped from the coverslips and placed in $2 \mathrm{ml}$ of $1 \%$ SDS, $10 \mathrm{mM}$ sodium borate solution for $2 \mathrm{~h}$ to dissolve the cells. Aliquots of the medium containing dissolved cells were assayed for radioactivity in a scintillation spectrometer (LKB Instruments Co.) and for protein content. ${ }^{45} \mathrm{Ca}$ influxes were expressed in nanomoles per milligram protein. This provides a valid basis for comparison under our experimental conditions because $T_{3}$ did not alter significantly either the number of cells or protein content per plate during the 48-h exposure used in these studies (see below).

Cytosolic free $\mathrm{Ca}$ measurements. Intracellular free $\mathrm{Ca}$ concentration $\left([\mathrm{Ca}]_{\mathrm{i}}\right)$ was measured using the Ca-sensitive fluorescent dye fura-2. The permeant fura-2 AM enters the cell and the impermeant fura- 2 produced as consequence of esterase action is trapped inside the cell. Cells grown on $12 \times 30$-mm rectangular glass coverslips were loaded with $2 \mu \mathrm{M}$ fura-2 $\mathrm{AM}$ in culture medium for $20 \mathrm{~min}$ at $37^{\circ} \mathrm{C}$. The cells were then washed for $20 \mathrm{~min}$ in Hepes-buffered medium to remove extracellular and bound dye. The glass coverslip was placed into a quartz cuvette which was then placed in the cuvette holder of a Fluorolog 2 fluorimeter (Spex Industries, Inc., Edison, NJ) equipped with magnetic stirrer and temperature control. Fura-2 fluorescence from the cells was continuously monitored at $505 \mathrm{nM}$ emission wavelength. The dual excitation wave- lengths were 340 and $380 \mathrm{nM}$. The relationship between fluorescence ratio $(340 \mathrm{~nm} / 380 \mathrm{~nm})$ and $[\mathrm{Ca}]_{i}$ was determined using the equations reported by Grynkiewicz et al. (28).

Contractility measurements. Changes in the contractile state of individual cells in the monolayers were assessed by the use of an opticalvideo system as previously described (20). After a 15-min equilibration period in serum-free medium, cells were superfused with desired test media, and the amplitude of cell motion and the first derivative of cell motion with respect to time were recorded in micrometers and micrometers per second, respectively.

Cell density correction. To normalize ion flux and content data for cell density on each coverslip, the monolayers were incubated in $\left[{ }^{3} \mathrm{H}\right]$ leucine $(0.2 \mathrm{Ci} / \mathrm{ml})$ for $48 \mathrm{~h}$ before each experiment. ${ }^{3} \mathrm{H}$ and ${ }^{45} \mathrm{Ca}$ counts were simultaneously determined for each coverslip using standard double-label counting methods, allowing normalization of ${ }^{45} \mathrm{Ca}$ content relative to milligrams cell protein for each coverslip after the relationship of ${ }^{3} \mathrm{H}$ counts to protein content had been determined.

Miscellaneous. Insulin, transferrin, progesterone, and $\mathrm{T}_{3}$ were purchased from Sigma Chemical Co., St. Louis, MO. Selenium ("Spectrapure") was purchased from United Mineral and Chemical Corp:, New York, NY. Insulin-containing solutions were filtered through a Millix GV filter (Millipore Corp., Bedford, MA), pore size, $0.22 \mu \mathrm{M}$. BAY k 8644 was a gift from Miles Laboratories, Inc., New Haven, CT. Statistical analyses were performed using Student's $t$ test (paired) or two-way analysis of variance.

\section{Results}

Effect of $T_{3}$ on the number of slow Ca channels. Ca movement across the cardiac sarcolemmal membrane and sarcoplasmic reticulum properties have been reported to be influenced by thyroid state $(4,11,15)$. To test the hypothesis that altered $\mathrm{Ca}$ handling by the sarcolemmal membrane may involve a change in the number of slow Ca channels (and consequently Ca permeability) of the sarcolemmal membrane, we examined the effect of growth of cells with or without $10 \mathrm{nM} \mathrm{T}$ on the number of slow Ca channels. Cultured chick ventricular cells were grown in serumcontaining medium for $48 \mathrm{~h}$ and then grown in serum-free, chemically defined medium with or without $10 \mathrm{nM} \mathrm{T}$ for an additional $48 \mathrm{~h}$. The number of slow $\mathrm{Ca}$ channels in the plasma membrane of intact cells was then determined using ${ }^{3} \mathrm{H}-\mathrm{PN} 200-$ 110 , a potent $\mathrm{Ca}$ channel blocker. Compared with cells grown in the absence of $\mathrm{T}_{3}$, cells grown in $10 \mathrm{nM} \mathrm{T} \mathrm{T}_{3}$ had $67 \%$ more Ca channels as judged by specific binding of ${ }^{3} \mathrm{H}-\mathrm{PN} 200-110$ (Table I; Fig. 1). $T_{3}$ had no statistically significant effect on ligand affinity. Because the total protein content, cell number per plate, and cell surface area values were not significantly different in the two groups of cells (see below), these results indicate that the number of slow $\mathrm{Ca}$ channels per cell increased significantly following $48 \mathrm{~h}$ exposure to $\mathrm{T}_{3}$.

We then determined the number of beta-adrenergic receptors in the sarcolemmal membrane to determine whether growth in the presence of elevated thyroid hormone levels causes an increase in beta-adrenergic receptor number in cultured chick heart cells, as it does in cardiac muscle cells of other species (29-31). Using the hydrophilic ligand ${ }^{3} \mathrm{H}$-CGP12177, a beta-adrenergic antagonist that selectively binds to cell surface beta receptors, we determined the number of ${ }^{3} \mathrm{H}$-CGP12177 binding sites expressed on intact cells (Fig. 1). As summarized in Table I, cells grown in $10 \mathrm{nM} \mathrm{T}_{3}$ bound $24 \%$ more ${ }^{3} \mathrm{H}$-CGP12177 than cells grown without $T_{3}$. No significant change in the affinity of antagonist for beta-adrenergic receptors occurred. Therefore, the numbers of both slow $\mathrm{Ca}$ channels and beta-adrenergic receptors 
Table I. Effect of $T_{3}$ on Numbers of Slow Calcium Channels and Beta-Adrenergic Receptors in Cultured Heart Cells

\begin{tabular}{lllll}
\hline$T_{3}$ & $\begin{array}{l}\text { Number of } \\
\text { slow Ca channels }\end{array}$ & $K_{d}$ & $\begin{array}{l}\text { Number of } \\
\beta \text {-adrenergic receptors }\end{array}$ & $K_{d}$ \\
\hline & $f m o l / m g$ protein & $p M$ & fmol/mg protein & $p M$ \\
0 & $35.5 \pm 5.2$ & $100 \pm 35$ & $27.6 \pm 3.8$ & $343 \pm 40$ \\
$10 \mathrm{nM}$ & $59.4 \pm 4.9^{*}$ & $222 \pm 61$ & $35.2 \pm 3.2^{*}$ & $348 \pm 62$ \\
\hline
\end{tabular}

Cells grown in medium with or without $10 \mathrm{nM} \mathrm{T}_{3}$ were incubated with ${ }^{3} \mathrm{H}-\mathrm{PN} 200-110$ or ${ }^{3} \mathrm{H}-\mathrm{CGP} 12177$ and binding was allowed to reach steady state at $37^{\circ} \mathrm{C}(30 \mathrm{~min})$. Binding was terminated by rapid wäshing of cells with cold Hepes-buffered solution. Cells were solubilized, and radioactivity and protein content in aliquots of dissolved cells were assayed. Specific binding for each ligand is the total binding minus nonspecific binding observed in the presence of nonlabeled ligands as described in Methods. Each value is the mean \pm SEM of five determinations.

* Significantly greater compared with the value observed in cells grown without $\mathrm{T}_{3}(P<0.05)$.

are significantly increased by $48 \mathrm{~h}$ of exposure of cells to 10 $\mathrm{nM} \mathrm{T}$.

Effect of $T_{3}$ on cell function and growth. Thyroid hormone is well known to affect contractile function as well as growth of cardiac muscle cells. We have reported previously that growth of cultured chick embryo ventricular cells in $10 \mathrm{nM} \mathrm{T}_{3}$ for 48 $h$ increases the rate of spontaneous contractions and the velocity of cell motion compared with cells grown in the absence of $T_{3}$ (4). We examined these properties and also the growth properties of cells grown with or without $10 \mathrm{nM} \mathrm{T}_{3}$ for 2-5 d. Growth of cells was studied by determining total protein content, numbers of cells per plate, and relative surface area of cells. Surface area was determined from the area of the two-dimensional image of the cells magnified 200 -fold on the TV screen. Table II shows the results of these measurements. As reported earlier (19), the rate of beating and the velocity of cell motion were significantly increased in cells grown in $10 \mathrm{nM} \mathrm{T}_{3}$ compared with values for cells grown in the absence of $T_{3}$. Mean total protein content per plate was not significantly different in the two groups of cells at day 1,2 , or 5 . Surface area of the cells was also not measurably altered by 48 -h growth in $T_{3}$. Because changes in the numbers of slow $\mathrm{Ca}$ channels and beta-adrenergic receptors occur without any corresponding change in cell size in cells grown with or

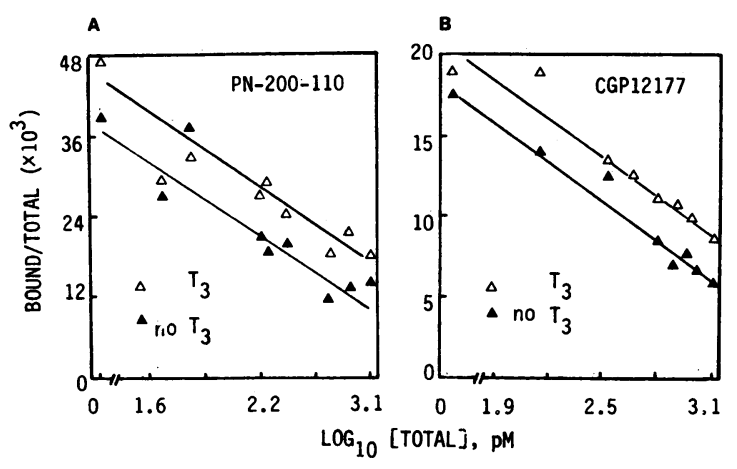

Figure 1. Binding of PN200-110 and of CGP12177 to intact cells. $(A)$ ${ }^{3} \mathrm{H}-\mathrm{PN} 200-110$ equilibrium binding was conducted in cells grown in 0 (closed circles) or $10 \mathrm{nM}$ (open circles) $\mathrm{T}_{3}$. Figure shows a representative experiment performed on parallel cultures simultaneously as described in Methods. This experiment was replicated five times with similar results. On average, there was no change in dissociation constant $\left(K_{d}\right)$ for PN200-110 but a 67\% increase in PN200-110 binding sites. $(B) \mathrm{A}$ representative ${ }^{3} \mathrm{H}-\mathrm{CGP} 12177$ equilibrium binding experiment, as in $A$. On average, there was no significant change in $K_{d}$ for CGP12177 but a 24\% increase in receptor number for cells grown in $10 \mathrm{nM} \mathrm{T}_{3}$.

without $T_{3}$, we conclude that $T_{3}$ increases the numbers of slow Ca channels and beta-adrenergic receptors per unit cell surface as well as per milligram protein.

$\mathrm{Ca}$ fluxes. We next determined whether alterations in the number of slow $\mathrm{Ca}$ channels are associated with corresponding changes in $\mathrm{Ca}$ flux via slow $\mathrm{Ca}$ channels. Cells grown in medium with or without $10 \mathrm{nM} \mathrm{T}$ for $48 \mathrm{~h}$ were incubated in Hepesbuffered medium containing ${ }^{45} \mathrm{Ca}$. The ${ }^{45} \mathrm{Ca}$ uptake by the cells was determined in the presence and absence of $10 \mu \mathrm{M}$ nifedipine, a potent dihydropyridine $\mathrm{Ca}$ channel blocker. We specifically examined ${ }^{45} \mathrm{Ca}$ uptake over an interval of $10 \mathrm{~s}$, a time during which ${ }^{45} \mathrm{Ca}$ flux is essentially unidirectional with minimal ${ }^{45} \mathrm{Ca}$ efflux. Nifedipine caused cessation of spontaneous beating in cultured chick heart cells grown with or without $T_{3}$. Therefore, a fraction of the decrease in ${ }^{45} \mathrm{Ca}$ uptake produced by nifedipine could be due to the absence of beating. However, nifedipine did not abolish action potentials during the $10 \mathrm{~s}$ of exposure, although action potential duration was shortened significantly (data not shown). Therefore, the difference in ${ }^{45} \mathrm{Ca}$ uptake observed in the presence and absence of nifedipine was taken as an indication of ${ }^{45} \mathrm{Ca}$ influx via slow $\mathrm{Ca}$ channels. The nifedipine-sensitive

Table II. Effect of $T_{3}$ on Contractile and Growth Properties of Cultured Heart Cells

\begin{tabular}{lllll}
\hline$T_{3}$ & $\begin{array}{l}\text { Days } \\
\text { in culture }\end{array}$ & Beating rate & $\begin{array}{l}\text { Velocity } \\
\text { of cell motion }\end{array}$ & $\begin{array}{l}\text { Surface area } \\
\text { per cell }\end{array}$ \\
\hline & & per $\min$ & $\mu \mathrm{m} / \mathrm{s}$ & $\mu \mathrm{s}$ per plate \\
0 & 2 & $106 \pm 6(14)$ & $30.6 \pm 3.3(14)$ & $282 \pm 21(12)$ \\
$10 \mathrm{nM}$ & 2 & $132 \pm 7(14)^{*}$ & $39.1 \pm 4.2(14)^{*}$ & $285 \pm 18(12)$ \\
0 & 5 & $124 \pm 5(12)$ & $26.3 \pm 3.9(12)$ & $340 \pm 31(12)$ \\
$10 \mathrm{nM}$ & 5 & $141 \pm 6(12)^{*}$ & $33.2 \pm 2.7(12)^{*}$ & $361 \pm 28(12)$
\end{tabular}

Cells grown in the presence or absence of $10 \mathrm{nM} \mathrm{T}_{3}$ for $48 \mathrm{~h}$ or $5 \mathrm{~d}$ were visualized using an optical-video system. Beating rates, velocity of cell motion, and surface area of the cells were determined. Protein contents were determined after $48 \mathrm{~h}$ or $5 \mathrm{~d}$ of growth. Values given are means \pm SEM; $n$ values are given in parentheses. * Significantly greater compared with the value observed in cells grown without $\mathrm{T}_{3}(P<0.05)$. 
${ }^{45} \mathrm{Ca}$ uptake was significantly greater $(+57 \% ; P<0.05)$ in cells grown in $10 \mathrm{nM} \mathrm{T}_{3}$ than in no $\mathrm{T}_{3}$, indicating that the amount of $\mathrm{Ca}$ entering the cells per unit time was sensitive to thyroid hormone (Table III). The nifedipine-insensitive ${ }^{45} \mathrm{Ca}$ uptake was also significantly greater in cells grown with $T_{3}$ than without $T_{3}$. This is in agreement with our previous observations (4) and suggests that the pathway by which the increased nifedipineinsensitive $\mathrm{Ca}$ entry occurs in $\mathrm{T}_{3}$-grown cells may be $\mathrm{Na}$-Ca exchange.

The Ca channel agonist BAY k 8644 has been shown to increase $\mathrm{Ca}$ channel conductance in cardiac muscle cells (32, 33). We tested the hypothesis that cardiac myocytes grown in the presence of $\mathrm{T}_{3}$ (and therefore having an increased number of slow Ca channels) have augmented Ca channel permeability changes in response to BAY $\mathbf{k} 8644$. Cells were preincubated in Ca-free medium for $5 \mathrm{~min}$ and then incubated in Ca-containing medium with ${ }^{45} \mathrm{Ca}$. Under the conditions of our experiments, 1 $\mu \mathrm{M}$ BAY $\mathrm{k} 8644$ or $10 \mu \mathrm{M}$ nifedipine produced maximal effects on ${ }^{45} \mathrm{Ca}$ uptake. Therefore, we used these concentrations of BAY k 8644 and nifedipine. As shown in Table III, addition of $1 \mu \mathrm{M}$ BAY k 8644 to the preincubation and uptake media significantly augmented ${ }^{45} \mathrm{Ca}$ uptake in cells grown with or without $\mathrm{T}_{3}$. Addition of $10 \mu \mathrm{M}$ nifedipine to the media significantly decreased ${ }^{45} \mathrm{Ca}$ uptake compared with control and blocked the BAY $\mathrm{k}$ 8644 -induced increase in ${ }^{45} \mathrm{Ca}$ uptake. The increase in the nifedipine-sensitive ${ }^{45} \mathrm{Ca}$ uptake rate produced by BAY $\mathrm{k} 8644$ was significantly greater $(+31 \% ; P<0.05)$ in cells grown in 10

Table III. Effect of $\mathrm{T}_{3}$ on ${ }^{45} \mathrm{Ca}$ Uptake

\begin{tabular}{llll}
\hline $\mathrm{T}_{3}$ & Drugs & ${ }^{4 s} \mathrm{Ca}$ uptake & $\begin{array}{l}\text { Nifedipine-sensitive } \\
\text { 4SCa uptake }\end{array}$ \\
\hline & & $\begin{array}{l}\text { nmol/mg } \\
\text { protein/min }\end{array}$ & $\begin{array}{l}\text { nmol/mg } \\
\text { protein/min }\end{array}$ \\
0 & & $3.05 \pm 0.14$ & $0.72 \pm 0.18$ \\
$10 \mathrm{nM}$ & & $3.98 \pm 0.18^{*}$ & $1.13 \pm 0.16^{*}$ \\
0 & Nifedipine & $2.33 \pm 0.11$ & \\
$10 \mathrm{nM}$ & Nifedipine & $2.85 \pm 0.12^{*}$ & \\
0 & BAY k 8644 & $5.46 \pm 0.21$ & $1.21 \pm 0.17$ \\
$10 \mathrm{nM}$ & BAY k 8644 & $6.41 \pm 0.23^{*}$ & $1.58 \pm 0.11^{*}$ \\
0 & Nifedipine & & \\
$10 \mathrm{nM}$ & Nifedipine & $4.25 \pm 0.31$ & \\
& + BAY k 8644 & $4.83 \pm 0.19^{*}$ & \\
& & &
\end{tabular}

Cells grown in the presence or absence of $10 \mathrm{nM} \mathrm{T}$ were incubated in Hepes-buffered medium, pH 7.35, containing ${ }^{45} \mathrm{Ca}$ with or without 10 $\mu \mathrm{M}$ nifedipine, $1 \mu \mathrm{M}$ BAY k 8644 , or nifedipine plus BAY $\mathrm{k} 8644$ for $10 \mathrm{~s}$. Experiments with BAY k 8644 were done using separate cultures (see Methods for detailed experimental procedures). Drugs were present in preincubation medium for $5 \mathrm{~min}$ before ${ }^{45} \mathrm{Ca}$ uptake experiments. Cells were then washed, dissolved, and assayed for ${ }^{45} \mathrm{Ca}$ and protein content. ${ }^{45} \mathrm{Ca}$ uptake is expressed as $\mathrm{nmol} / \mathrm{mg}$ protein $/ \mathrm{min}$. Each value is the mean \pm SEM of eight determinations. Because the experimental procedures for ${ }^{45} \mathrm{Ca}$ uptake were different when using BAY $k$ 8644, the uptake values on the bottom half of the table cannot be compared to those on the top half.

* Significantly greater than the value observed in cells grown in no $T_{3}$ $(P<0.05)$
$\mathrm{nM} \mathrm{T}_{3}(1.58 \mathrm{nmol} / \mathrm{mg}$ protein $/ \mathrm{min})$ than in cells grown without added $\mathrm{T}_{3}(1.21 \mathrm{nmol} / \mathrm{mg}$ protein $/ \mathrm{min})$.

Cytosolic free $\mathrm{Ca}$. Alterations in the number of slow $\mathrm{Ca}$ channels would be expected to be associated with changes in the cytosolic free $\mathrm{Ca}$ response to $\mathrm{Ca}$ channel agonist or beta-adrenergic agonist exposure. To test this hypothesis, we determined the effects of BAY k 8644 or isoproterenol on time-averaged $[\mathrm{Ca}]_{\mathrm{i}}$ in cells grown with or without $10 \mathrm{nM} \mathrm{T}_{3}$. Fig. 2 shows the changes in fluorescence intensity observed in fura- 2 loaded cells in response to BAY k 8644 and isoproterenol. Rapid exchange of Hepes-buffered medium (control) to that containing $1 \mu \mathrm{M}$ BAY $\mathrm{k} 8644$ or $1 \mu \mathrm{M}$ isoproterenol produced a gradual increase in $[\mathrm{Ca}]_{\mathrm{i}}$ that reached a plateau by 4-5 $\mathrm{min}$. This increase in $[\mathrm{Ca}]_{i}$ was temporally related to the positive contractile response induced by BAY k 8644 or isoproterenol (see below). Nifedipine $(10 \mu \mathrm{M})$ reduced $[\mathrm{Ca}]_{i}$ and abolished the effects of BAY $\mathrm{k} 8644$ or isoproterenol on $[\mathrm{Ca}]_{i}$, as expected. The changes in $[\mathrm{Ca}]_{i}$ produced by BAY $\mathbf{k} 8644$ or isoproterenol in cells grown with or without $T_{3}$ are summarized in Table IV. In the absence of drugs, no significant differences in $[\mathrm{Ca}]_{i}$ were noted in the two groups of cells. Because we measured the time-averaged $[\mathrm{Ca}]_{i}$ and the beating rates are significantly different in cells grown in the presence and absence of $T_{3}$, comparisons of time-averaged $[\mathrm{Ca}]_{i}$ values do not indicate how systolic and diastolic $[\mathrm{Ca}]_{i}$ values may be affected. It is possible, however, to measure changes in mean $[\mathrm{Ca}]_{\mathrm{i}}$ produced by BAY $\mathbf{k} 8644$ or isoproterenol. BAY k 8644 produced a $2.2-$ or a 2.9 -fold increase, and isoproterenol produced a 1.3- or 1.5-fold increase in [Ca $]_{i}$ in cells grown in 0 or $10 \mathrm{nM} \mathrm{T}_{3}$, respectively. Thus, both BAY k 8644 and isoproterenol caused a significantly greater increase in $[\mathrm{Ca}]_{i}$ in cells exposed to elevated thyroid hormone concentrations $(P<0.05)$. These results indicate that an increase in the number of slow $\mathrm{Ca}$ channels is associated with an increased $[\mathrm{Ca}]_{i}$ in response to interventions known to activate $\mathrm{Ca}$ channels. In the case of isoproterenol, the greater increase in $[\mathrm{Ca}]_{i}$ observed in cells grown in $T_{3}$ is presumably due to a combination of increases in both beta-adrenergic receptors and slow $\mathrm{Ca}$ channels.

It has been reported that dihydropyridine $\mathrm{Ca}$ channel antagonists have a higher affinity for the inactivated (depolarized) state of Ca channels $(34,35)$. Because $T_{3}$ increases beating rate (4), we considered the possibility that the greater increase in [Ca $]_{i}$ produced by BAY $\mathrm{k} 8644$ in $\mathrm{T}_{3}$-grown cells compared with cells grown without $T_{3}$ was due to the difference in the rate of spontaneous beating. To test this hypothesis, cells grown without $\mathrm{T}_{3}$ were equilibrated in either 3.5 or $5 \mathrm{mM} \mathrm{K}^{+}$medium (producing beating rates of $118 \pm 7$ or $92 \pm 5$, respectively), and the changes in $[\mathrm{Ca}]_{\mathrm{i}}$ in response to BAY $\mathrm{k} 8644$ were determined. At steady state, BAY k 8644 increased [Ca $]_{i}$ from $126 \pm 21$ to $244 \pm 26 \mathrm{nM}$ in $3.5 \mathrm{mM} \mathrm{K}_{0}$ medium and from $118 \pm 27$ to $261 \pm 33$ $\mathrm{nM}$ in $5 \mathrm{mM} \mathrm{K}^{+}$medium. Therefore, BAY $\mathrm{k}$ 8644-induced increases in $[\mathrm{Ca}]_{\mathrm{i}}$ were similar in both groups of cells despite the difference in beating rate, supporting the view that the larger increase in $[\mathrm{Ca}]_{i}$ produced by BAY k 8644 in $\mathrm{T}_{3}$-treated cells is due to factors other than beating rate. Although the beating rate increases in $\mathrm{T}_{3}$-grown cells, the total fraction of time $\mathrm{Ca}$ channels spend in the depolarized state may not be appreciably different from that in cells grown without $T_{3}$, because the plateau phase of the action potential tends to become shorter with increasing beating rates.

Contractile state. To examine the relationship between the number of slow $\mathrm{Ca}$ channels and physiologic function, we de- 


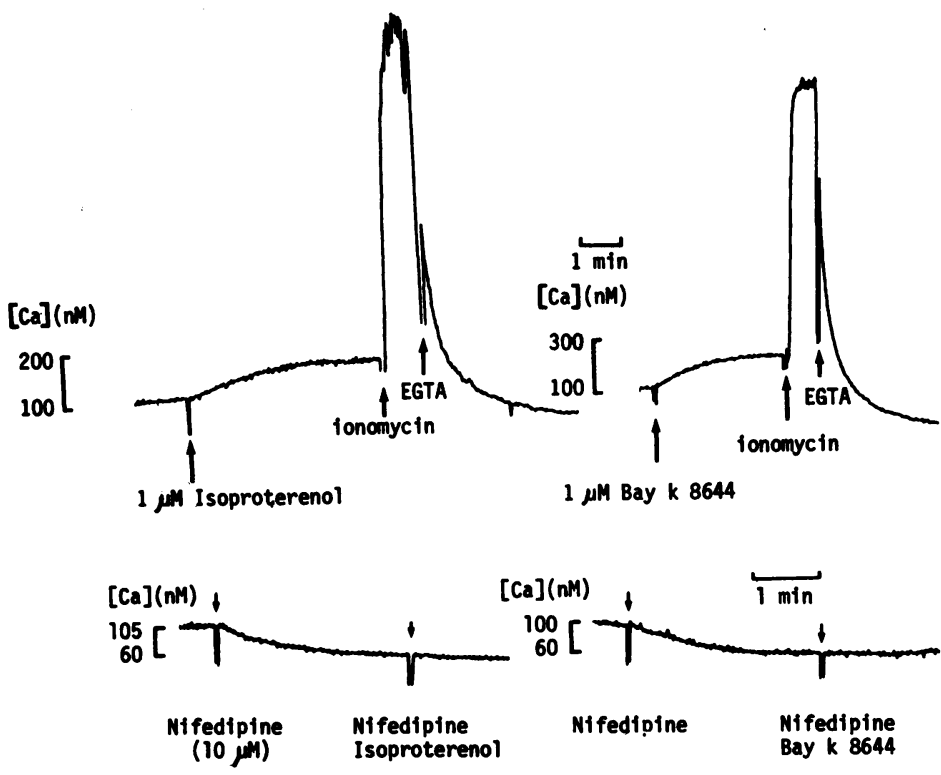

Figure 2. Effects of nifedipine, isoproterenol, and BAY k 8644 on $[\mathrm{Ca}]_{\mathrm{i}}$. Cells grown with or without $10 \mathrm{nM} \mathrm{T}_{3}$ were loaded with fura-2 and then equilibrated in Hepes-buffered medium for $10 \mathrm{~min}$. Fluorescence from the cells was continuously recorded. The cells were then exposed to medium containing $1 \mu \mathrm{M}$ BAY $\mathbf{k}$ 8644 or $1 \mu \mathrm{M}$ isoproterenol and changes in fluorescence intensity ratio $(340 \mathrm{~nm} / 380 \mathrm{~nm})$ were monitored until a new steady-state level was reached. Fluorescence intensity ratio was calibrated to give actual [Ca] by the following method. When the steady-state level of fluorescence was reached, $4 \mu \mathrm{M}$ ionomycin was added to the medium containing the cells to allow equilibration of intracellular and extracellular $\mathrm{Ca}$. When the fluorescence reached the maximal level, EGTA $(5 \mathrm{mM})$ was further added to reduce $[\mathrm{Ca}]_{i}$ to near zero levels. The equation described by Grynkiewicz et al. (28) was then used to calculate [Ca] from the fluorescence intensities. The tracings shown below are obtained from cells grown in $10 \mathrm{nM} \mathrm{T}_{3}$ for $48 \mathrm{~h}(n=5)$. termined the effect of BAY k 8644 on contractile state. Cells were perfused with control Hepes-buffered medium for $10 \mathrm{~min}$ and then with the same medium containing $1 \mu \mathrm{M}$ BAY $\mathrm{k} 8644$. BAY k 8644 produced a gradual increase in the amplitude of cell motion that reached steady state by 4-5 min. In each experiment, $3.6 \mathrm{mM} \mathrm{Ca}$ produced maximal increases in the amplitude and velocity of cell motion that were then taken as a $100 \%$ increase for comparison purposes. In cells grown in medium without $T_{3}$, BAY $k 8644$ increased the amplitude of cell motion by $51.4 \pm 5.7 \%$. In cells grown in $10 \mathrm{nM} \mathrm{T}_{3}, \mathrm{BAY} \mathrm{k} 8644$ increased the amplitude of cell motion by $59.2 \pm 5.6 \%$. BAY $k$ 8644 also augmented the velocity of cell motion in both groups of cells but no statistically significant differences in the increase were present $(P>0.05)$. Therefore, despite a greater increase in [Ca $]_{i}$ produced by BAY $k 8644$ in cells grown in $10 \mathrm{nM} \mathrm{T}_{3}$, we could not detect a statistically significant difference in the augmentation of amplitude or velocity of cell motion in the two groups of cells.

Table IV. Effect of Isoproterenol and BAY $k 8644$ on $[\mathrm{Ca}]_{i}$

$\left.\begin{array}{llll}\hline \mathrm{T}_{3} & \text { Control } & \text { BAY k 8644 } & \text { Isoproterenol } \\ \hline & n M & n M & n M \\ 0 & 105.5 \pm 22.3 & 224.2 \pm 30.5^{*} \\ 10 \mathrm{nM} & 102.0 \pm 22.4 & 286.5 \pm 30.9^{*}\end{array}\right\} \neq \begin{aligned} & 125.0 \pm 18.4^{*} \\ & \end{aligned}$

Cells grown with or without $10 \mathrm{nM} \mathrm{T}_{3}$ were loaded with fura-2 and then equilibrated in Hepes-buffered medium (pH 7.35) for 10 min. Fluorescence from the cells was continuously monitored. The cells were then exposed to medium containing $1 \mu \mathrm{M}$ BAY K 8644 or $1 \mu \mathrm{M}$ isoproterenol, and changes in fluorescence intensities were monitored until a new steady state was reached. Fluorescence intensities were then calibrated to give actual [Ca] values (see legend to Fig. 1). Each value is the mean $\pm S E M$ of five determinations.

* Significantly greater than the paired control value $(P<0.05)$.

${ }^{\ddagger}$ Significantly different $(P<0.05)$.

\section{Discussion}

The present study demonstrates that in cultured chick ventricular cells, thyroid hormone $\left(\mathrm{T}_{3}\right)$ modulates the expression of dihydropyridine binding sites, which very likely represent $\mathrm{Ca}$ channels in the sarcolemmal membrane. Analogous to the effects of $T_{3}$ on the numbers of sodium pump sites and beta-adrenergic receptors $(17-19,29,30)$, cardiac myocytes grown in high levels of $\mathrm{T}_{3}$ possessed greater numbers of dihydropyridine binding sites compared with cells grown without $T_{3}$. The increased number of binding sites was associated with an enhanced baseline contractile state and greater sarcolemmal $\mathrm{Ca}$ flux. There was also a greater increase in time-averaged $[\mathrm{Ca}]_{i}$ in response to the $\mathrm{Ca}$ channel agonist BAY k 8644 and to isoproterenol. Taken together, these observations suggest that a hormone acting via a nuclear receptor (and presumably enhancing expression of a gene or group of genes) alters the expression of functional $\mathrm{Ca}$ channels.

Thyroid hormone-induced increases in myocardial contractility in the rat and rabbit have been attributed to changes in the proportions of V1 and V3 myosin isoenzymes, with the $\mathrm{V} 1$ isoenzyme form with higher ATPase activity increasing in response to thyroid hormone. Studies of isolated preparations of isolated sarcoplasmic reticulum from dog and rabbit hearts indicate that thyroid hormone also increases $\mathrm{Ca}$ uptake and loading of this organelle (9-14). Furthermore, thyroid hormone has been reported to stimulate sarcolemmal membrane $\mathrm{Ca}$ ATPase (16). Thus, Ca movements across the membranes of the sarcolemma and sarcoplasmic reticulum of heart muscle appear to be altered by exposure to elevated thyroid hormone levels. We have shown previously that in cultured chick ventricular cells, unidirectional $\mathrm{Ca}$ flux rates across the sarcolemmal membrane as well as the size of the rapidly exchangeable $\mathrm{Ca}$ pool are increased in cells grown in the presence of $\mathrm{T}_{3}$ compared with cells grown in its absence (4). The results of the present study indicate that the mechanism underlying the changes in transmembrane $\mathrm{Ca}$ transport involve increased slow channel $\mathrm{Ca}$ flux associated with increased dihydropyridine binding sites in 
cells exposed to $10 \mathrm{nM} \mathrm{T}$ for $48 \mathrm{~h}$. The greater augmentation of slow channel Ca flux in response to BAY $k 8644$ in cells grown with $T_{3}$ is probably also related to an increased number of slow Ca channels in these cells. Studies with fura-2-loaded cells show that BAY k 8644 produces a significantly greater increase in time-averaged $[\mathrm{Ca}]_{i}$ in cells grown with $T_{3}$ than without $T_{3}$, supporting the view that the increased numbers of dihydropyridine binding sites as judged by antagonist radioligand binding represent functional sites capable of mediating $\mathrm{Ca}$ entry.

Both PN200-110 and BAY k 8644 bind preferentially to the depolarized, largely inactivated state of the $\mathrm{Ca}$ channel. Bean (35) has shown that in canine ventricular cells, the affinity of a dihydropyridine for the calcium channel is more than 500 -fold higher for the inactivated state of the channel than for the resting state. The $T_{3}$-grown cells have a somewhat higher beating rate and thus are in the inactivated, high-affinity state for BAY $k$ 8644 more frequently and, hence, probably for a greater fraction of the time. This may account, in part, for the greater increase in $[\mathrm{Ca}]_{\mathrm{i}}$ in response to BAY $\mathrm{k} 8644$ in cells grown in $10 \mathrm{nM} \mathrm{T}_{3}$. However, in cells made to beat at mean rates of 92 or 118 per min by exposure to 5 or $3.5 \mathrm{mM} \mathrm{K}_{0}$ medium, respectively, BAY k 8644 produced similar increases in $[\mathrm{Ca}]_{i}$. This suggests that the significantly greater increase in [Ca] $]_{i}$ produced by BAY $k$ 8644 in $T_{3}$-grown cells compared with cells grown without $T_{3}$ is due to factors other than the small difference in beating rate.

Despite the greater increase in $[\mathrm{Ca}]_{\mathrm{i}}$ in response to BAY $\mathbf{k}$ 8644 in cells with higher numbers of dihydropyridine binding sites, the associated contractile response to the $\mathrm{Ca}$ channel agonist was not significantly different compared with that observed in cells with smaller numbers of slow $\mathrm{Ca}$ channels. We know of no precedent for decreased $\mathrm{Ca}$ sensitivity of contractile proteins in response to $T_{3}$. A more likely explanation for the similar percent increase in contractile amplitude response to BAY $\mathbf{k}$ 8644 in cells grown with or without $T_{3}$ may be that in the former cells, the basal velocity of cell contraction is closer to the maximal level than that of latter cells. It is expected that a cell that exhibits a lower level of force generation by the myofilaments will produce a greater percent increase in force when $[\mathrm{Ca}]_{i}$ is increased than a cell starting from a higher level of force generation, at least for the concave-downward portion of the $[\mathrm{Ca}]_{\text {-contractile effect }}$ curve.

In contrast to other studies showing that elevated thyroid hormone levels tend to cause hypertrophy $(36,37)$, total protein content (an estimate of cell growth) was not significantly different in our cultured chick embryo ventricular cell preparations during the first $48 \mathrm{~h}$ in the presence or absence of $10 \mathrm{nM} \mathrm{T}$. Carter et al. (38) reported that in cultured chick heart cells, $10 \mathrm{nM} \mathrm{T}_{3}$ caused a $16-21 \%$ increase in protein content during a 6-d exposure. In these studies, the increase in protein content after 48 $h$ of $T_{3}$ treatment was significantly smaller than that observed after $6 \mathrm{~d}$. The absence of a $T_{3}$ effect on protein content or on the size of the cells under the conditions of our experiments may be due to differences in growth media used. Conveniently, the lack of effect of $\mathrm{T}_{3}$ on cell growth during the interval observed allows a direct comparison of $\mathrm{Ca}$ channel and beta-adrenergic receptor number as well as changes in Ca fluxes in $\mathrm{T}_{3}$-treated and untreated cells, unencumbered by problems of normalization for cell size or considerations related to cell cycle in dividing myocytes. Even if a small difference in protein content were present, our data indicate that the changes in $\mathrm{Ca}$ channel and beta receptor number and $[\mathrm{Ca}]_{i}$ observed in this study are of sufficient magnitude so that they could not be accounted for solely by small differences in protein content.

We have shown previously that in cultured chick heart cells, $\mathrm{T}_{3}$ increases the number of $\mathrm{Na}$ pump sites in the cell membrane by 1.6 -fold (19). Whether such changes are functionally related to the increased $\mathrm{Ca}$ uptake rate reported here is not clear. The available findings on the actions of $\mathrm{T}_{3}$ do not suggest any specific relationship between an increased $\mathrm{Ca}$ uptake rate and the number of sodium pump sites. Because elevated numbers of Na pump sites were associated with reduced steady-state cellular Na content (19), the decreased $[\mathrm{Na}]_{\mathrm{i}}$ would be expected to be associated with reduced $\mathrm{Ca}$ influx via $\mathrm{Na}-\mathrm{Ca}$ exchange. Because the ${ }^{45} \mathrm{Ca}$ uptake rate was significantly increased in $\mathrm{T}_{3}$-treated cells despite the reduced $[\mathrm{Na}]_{i}, \mathrm{Ca}$ uptake via pathways other than $\mathrm{Na}-\mathrm{Ca}$ exchange is likely increased. This is in keeping with the results of the present study that growth in $\mathrm{T}_{3}$ augments $\mathrm{Ca}$ uptake via slow $\mathrm{Ca}$ channels. It is also possible that growth in $\mathrm{T}_{3}$ alters the number of $\mathrm{Na}-\mathrm{Ca}$ exchangers or the affinity of the exchanger for $\mathrm{Na}$ and/or $\mathrm{Ca}$, leading to increased $\mathrm{Ca}$ uptake via $\mathrm{Na}-\mathrm{Ca}$ exchange. Our previous study (4) showing that Na-dependent Ca uptake was elevated in cells grown in $T_{3}$ compared with no $\mathrm{T}_{3}$ supports the view that $\mathrm{Ca}$ influx via $\mathrm{Na}-\mathrm{Ca}$ exchange may also be increased by growth in the presence of $T_{3}$.

In conclusion, thyroid hormone exposure increased the number of slow $\mathrm{Ca}$ channels and beta-adrenergic receptors in the sarcolemmal membrane of cultured chick heart cells. The increased myocardial contractility observed in the hyperthyroid heart appears to be due in part to increased numbers of slow $\mathrm{Ca}$ channels and, consequently, increased $\mathrm{Ca}$ influx via slow $\mathrm{Ca}$ channels. The Ca channel agonist, BAY k 8644, produced a greater increase in $\mathrm{Ca}$ uptake and $[\mathrm{Ca}]_{\mathrm{i}}$ in cells grown with than without $T_{3}$, further supporting the view that thyroid hormone modulates the number of functional $\mathrm{Ca}$ channels in the sarcolemmal membrane.

\section{Acknowledgments}

The authors thank Ms. Kathleen Sweeney and Ms. Sara Kacprowicz for their expert technical assistance and Ms. Susan McHale for preparation of the manuscript.

This work was supported by grants HL-18003, HL-26215, and HL00691 from National Heart, Lung, and Blood Institute and National Institutes of Health. Dr. Marsh is the recipient of a Clinical Investigator Award from National Institutes of Health.

\section{References}

1. Buccino, R. A., J. F. Spann, Jr., P. E. Pool, E. H. Sonnenblick, and $E$. Braunwald. 1967. Influence of the thyroid state on the intrinsic contractile properties and energy stores of the myocardium. J. Clin. Invest. 46:1669-1682.

2. Grossman, W., N. L. Rubin, and C. W. Johnson. 1971. The enhanced myocardial contractility of thyrotoxicosis. Ann. Intern. Med. 74: 869-874.

3. Morkin, E., I. L. Flink, and S. Goldman. 1983. Biochemical and physiological effects of thyroid hormone on cardiac performance. Prog. Cardiovasc. Dis. 25:435-464.

4. Kim, D., and T. W. Smith. 1985. Effects of thyroid hormone on calcium handling in cultured chick ventricular cells. J. Physiol. (Lond.). 364:131-149.

5. Crie, J. S., J. R. Wakeland, B. A. Mayhew, and K. Wildenthal. 1983. Direct anabolic effects of thyroid hormone on isolated mouse heart. Am. J. Physiol. 245:C328-C333. 
6. Brooks, I., S. B. Flynn, D. A. A. Owen, and A. H. Underwood. 1985. Changes in cardiac function following administration of thyroid hormones in thyroidectomized rats: assessment using the isolated working rat heart preparation. J. Cardiovasc. Pharmacol. 7:290-296.

7. Flink, I. L., J. H. Rader, and E. Morkin. 1979. Thyroid hormone stimulates synthesis of a cardiac myosin isozyme. Comparison of the two-dimensional electrophoretic patterns of the cyanogen bromide peptides of cardiac myosin heavy chains from euthyroid and thyrotoxic rabbits. J. Biol. Chem. 254:3105-3110.

8. Hoh, J. F. Y., P. A. McGrath, and P. T. Hale. 1978. Electrophoretic analysis of multiple forms of rat cardiac myosin: effects of hypophysectomy and thyroid replacement. J. Mol. Cell. Cardiol. 10:1053-1076.

9. Goodkind, M. J., G. E. Damback, P. T. Thyrum, and R. J. Luchi. 1974. Effect of thyroxine on ventricular myocardial contractility and ATPase activity in guinea pigs. Am. J. Physiol. 226:66-72.

10. Suko, J. 1971. Alterations of $\mathrm{Ca}^{++}$-activated ATPase of cardiac sarcoplasmic reticulum in hyper- and hypothyroidism. Biochim. Biophys. Acta. 252:324-327.

11. Suko, J. 1973. The calcium pump of cardiac sarcoplasmic reticulum. Functional alterations of different levels of thyroid state in rabbits. J. Physiol. (Lond.). 228:563-581.

12. Conway, G., R. A. Heazlitt, N. O. Fowler, M. Gabel, and S. Green. 1976. The effect of hyperthyroidism on the sarcoplasmic reticulum and myosin ATPase of dog heart. J. Mol. Cell. Cardiol. 8:39-51.

13. Nayler, W. G., N. C. R. Merrillees, D. Chipperfield, and J. B. Kurtz. 1971. Influence of hyperthyroidism on the uptake and binding of calcium by cardiac microsomal fractions and on mitochondrial structure. Cardiovasc. Res. 5:469-482.

14. Rodgers, R. L., S. Black, S. Katz, and J. H. McNeil. 1986. Thyroidectomy of SHR: effects on ventricular relaxation and on SR calcium uptake activity. Am. J. Physiol. 250:H861-H865.

15. Davis, P. J., and S. D. Blas. 1981. In vitro stimulation of human red blood cell $\mathrm{Ca}^{++}$-ATPase by thyroid hormone. Biochem. Biophys. Res. Commun. 99:1073-1080.

16. Rudinger, A., K. M. Mylotte, P. J. Davis, F. B. Davis, and S. D. Blas. 1984. Rabbit myocardial membrane $\mathrm{Ca}^{2+}$-adenosine triphosphatase activity: stimulation in vitro by thyroid hormone. Arch. Biochem. Biophys. 229:379-385.

17. Philipson, K. D., and I. S. Edelman. 1977. Thyroid hormone control of $\mathrm{Na}^{+}-\mathrm{K}^{+}$-ATPase and $\mathrm{K}^{+}$-dependent phosphatase in rat heart. Am. J. Physiol. 232:C196-C201.

18. Curfman, G. D., T. J. Crowley, and T. W. Smith. 1977. Thyroidinduced alterations in myocardial sodium- and potassium-activated adenosine triphosphatase, monovalent cation active transport, and cardiac glycoside binding. J. Clin. Invest. 59:586-590.

19. Kim, D., and T. W. Smith. 1984. Effects of thyroid hormone on sodium pump sites, sodium content and contractile response to cardiac glycosides in cultured chick ventricular cells. J. Clin. Invest. 74:14811488.

20. Barry, W. H., and T. W. Smith. 1982. Mechanisms of transmembrane calcium movements in cultured chick embryo ventricular cells. J. Physiol. (Lond.). 325:243-260.

21. Libby, P. 1984. Long-term culture of contractile mammalian heart cells in a defined serum-free medium that limits non-muscle cell proliferation. J. Mol. Cell. Cardiol. 16:803-811.
22. Ferry, D. R., A. Goll, and H. Glossman. 1983. Differential labelling of putative skeletal muscle calcium channels by ${ }^{3} \mathrm{H}$-nifedipine, ${ }^{3} \mathrm{H}$-nitrenodipine, ${ }^{3} \mathrm{H}$-nimodipine and ${ }^{3} \mathrm{H}-\mathrm{PN} 200-110$. Naunyn-Schmiedeberg's Arch. Pharmacol. 323:276-277.

23. Rengasamy, A., J. Ptasienski, and M. M. Hosey. 1985. Purification of the cardiac 1,4 dihydropyridine receptor/calcium channel complex. Biochem. Biophys. Res. Commun. 126:1-7.

24. Hertel, C., and M. Staehelin. 1983. Reappearance of $\beta$-adrenergic receptors after isoproterenol treatment in intact C-6 cells. J. Cell Biol. 97:1538-1543.

25. Marsh, J. D., and D. J. Roberts. 1987. Adenylate cyclase regulation in intact cultured myocardial cells. Am. J. Physiol. 252:C47-C54.

26. Lowry, O. H., N. J. Rosebrough, A. L. Farr, and R. J. Randall. 1951. Protein measurement with the Folin phenol reagent. J. Biol. Chem. 19:265-275.

27. Munson, P. J., and D. Rodbard. 1980. Ligand: a versatile computerized approach for characterization of ligand-binding systems. Anal. Biochem. 107:220-239.

28. Grynkiewicz, G., M. Poenie, and R. Y. Tsien. 1985. A new generation of $\mathrm{Ca}^{2+}$ indicators with greatly improved fluorescence properties. J. Biol. Chem. 260:3440-3450.

29. Williams, L. T., R. J. Lefkowitz, A. M. Watanabe, D. R. Hathaway, and H. R. Besch, Jr. 1977. Thyroid hormone regulation of Badrenergic receptor number. J. Biol. Chem. 252:2787-2789.

30. Niizoe, K., K. Ogawa, and T. Satake. 1984. Long-term effects of triiodothyronine and thiouracil on myocardial B-adrenergic receptor numbers and cyclic AMP concentration in rats. Jpn. Circ. J. 48:508514.

31. Tsai, J. S., and A. Chen. 1978. Effect of $l$-triiodothyronine on $(-)^{3} \mathrm{H}$-dihydroalprenolol binding and cyclic AMP response to (-)adrenaline in cultured heart cells. Nature (Lond.). 275:138-140.

32. Renaud, J. F., J. P. Meaux, G. Romey, A. Schmid, and M. Lazdunski. 1984. Activation of the voltage-dependent $\mathrm{Ca}^{++}$channel in rat heart cells by dihydropyridine derivatives. Biochem. Biophys. Res. Commun. 125:405-412.

33. Wahler, G. M., and N. Sperelakis. 1984. New Ca ${ }^{2+}$ agonist (Bay K 8644) enhanced and induces cardiac slow action potentials. Am. J. Physiol. 247:H337-H340.

34. Kokubun, S., B. Prod'hom, C. Becker, H. Porzig, and H. Reuter. 1986. Studies on Ca channels in intact cardiac cells: voltage-dependent effects and cooperative interactions of dihydrophyridine enantiomers. Mol. Pharmacol. 30:571-584.

35. Bean, B. P. 1984. Nitrendipine block of the cardiac calcium channels: high affinity binding to the inactivated state. Proc. Natl. Acad. Sci. USA. 81:6388-6392.

36. Klein, I., and C. Hong. 1986. Effects of thyroid hormone on cardiac size and myosin content of the heterotopically transplanted rat heart. J. Clin. Invest. 77:1694-1698.

37. Sanford, C. F., E. E. Griffin, and K. Wildenthal. 1978. Synthesis and degradation of myocardial protein during the development and regression of thyroxine-induced cardiac hypertrophy in rats. Circ. Res. 43:688-694.

38. Carter, W. J., W. S. van der W. Benjamin, and F. H. Faas. 1985. Effect of thyroid hormone on protein turnover in cultured cardiac myocytes. J. Mol. Cell. Cardiol. 17:897-905. 